\title{
El tiempo de las imágenes. Notas acerca de la Historia del Arte según Didi-Huberman ${ }^{1}$
}

\author{
Times of Images. Notes about History \\ of Art according to Didi-Huberman
}

\author{
RAMÓN MACHO ROMÁN \\ École Normale Supérieure de Paris \\ ramon.macho@ens.fr
}

Recibido: 10-09-2014

Aceptado: 01-09-2015

\section{Resumen}

Los ensayos sobre el método de la Historia del Arte de Georges Didi-Huberman proponen un refundación de la disciplina a partir de una crítica de los modelos de tiempo tradicionalmente asumidos por esta. Procuran sentar las bases de una nueva temporalidad - anacrónica y fantasmal - que permita pensar la imagen plástica en su esencial complejidad, apoyándose para ello en el pensamiento de algunos autores marginales (Walter Benjamin, Carl Einstein, Aby Warburg...). Este trabajo intenta reconstruir las líneas fundamentales de dicho planteamiento a través del análisis crítico de algunos de los comentarios que Didi-Huberman lleva a cabo acerca de las obras de estos pensadores.

Palabras clave: G. Didi-Huberman, A. Warburg, anacronismo, tiempo, supervivencia.

\footnotetext{
${ }^{1}$ Durante el mes de julio del año 2010 se impartió en la facultad de Bellas Artes de la Universidad Complutense de Madrid bajo la dirección de Catalina Ruiz Mollá y Pablo Perera Velamazán un curso cuyo título era El tiempo de las imágenes. En la voz de aquellos profesores escuché por primera vez el nombre de Georges Didi-Huberman. Soy consciente de todo lo les debe lo que escribo desde entonces, el contenido de este artículo me pertenece, pues, tan poco como su título. Agradezco aquí sus consejos y enseñanzas.
} 


\begin{abstract}
Georges Didi-Huberman's works about the method of History of Art suggest its re-foundation. It would start with the critic of the traditional time modeling. These works try to propose a new phantom-anachronistic temporality that allows thinking the essential complexity of plastic images. In order to prepare it, Didi-Huberman studies some marginal writers (Walter Benjamin, Carl Einstein, Aby Warburg...). This essay tries to define main characteristics of his proposal by analyzing critically some of Didi-Huberman's lectures about these thinkers.
\end{abstract}

Keywords: Didi-Huberman, Warburg, Anachronism, time, survival.

Memoria suya, dicen; te preguntas de qué, de quién, de cuándo, de qué muerte.

J.A. Valente

De alguien que guarda un secreto, que se resiste con firmeza a comunicarlo a los demás, se dice en castellano que es una tumba. Dicha expresión no alude tanto, o no solo, al riguroso silencio que solemos encontrar en los cementerios ni al hecho de que las tumbas, las lápidas o los nichos, los muertos o sus restos, nunca digan nada, como a cierta costumbre de acuerdo con la cual uno visita la tumba del difunto y habla con él. La tumba, en nombre del muerto, conservaría el secreto que alguien - que le recuerda y que para hablar con él se desplaza al cementerio - le ha contado. La expresión ser alguien una tumba alude entonces a una comunicación desigual que va en una sola dirección, del vivo al muerto, y que implica lo siguiente: que los muertos no hablan con los vivos. Puede que los escuchen, religiones y otras supersticiones mediante, pero no hablan con los vivos. La lógica limitada de la ontología tradicional sobre la que se asienta esta descripción, tal como escribió en cierta ocasión Jacques Derrida, debería ser sustituida, o al menos completada, por una ontología diferente, que él denominaba fantología, capaz de ampliar el campo de dicha comunicación al hacer intervenir - asediar - la figura de todo aquello de lo que en rigor no cabría decir que es presente. Puesto que los muertos, o mejor dicho, sus espectros y fantasmas, de hecho se habrían resistido tozudamente a permanecer recluidos en el interior de los cementerios y habrían tenido efectos sobre el presente vivo y actual - al que entonces no podría decirse que se contraponen unilateralmente como su reverso negativo - una lógica de lo fantasmal más potente que cualquier pensamiento sobre el ser del ente, debería estructurar de derecho el campo de esta cuasi-efectividad.

Como es sabido, la retórica de la fantasmagorización hizo fortuna. Fue asumida tanto por quienes venían dedicándose a la edificante tarea de hacer justicia en la 
historia - en la disciplina, porque en los sucesos por lo visto no se puede - como por aquellos que vieron en las oportunidades líricas que esta forma de hablar ofrecía un recurso socorrido para panfletos y aforismos poéticos. A caballo entre estas dos formas de asimilación de la propuesta derridiana se encuentran algunos de los trabajos del historiador del arte parisino Georges Didi-Huberman, los cuales, sin embargo, solo un gesto extremadamente tramposo podría querer reducir a las ingenuas y poco rigurosas formas de apropiación mencionadas.

En los ensayos dedicados a las llamadas cuestiones metodológicas de la Historia del Arte, Didi-Huberman ha hecho notables esfuerzos por poner de manifiesto la verdadera naturaleza de los objetos de su disciplina - las imágenes artísticas - así como por elaborar un modelo de tiempo capaz, si no de resolver, al menos sí de afrontar los problemas que dichas imágenes plantean al historiador. Se trata en ellos de establecer la ontología regional propia -aunque en rigor no podríamos seguir llamándola ontología- de los objetos de estudio de la Historia del Arte, que se sitúan en los límites de la lógica binaria tradicional. Esto lo liga cabalmente a las tesis de Derrida, quien reconocía que a lo largo de la historia de la filosofía ésta última solo había sido capaz de oponer presencia y ausencia aunque lo hiciera bajo distintos nombres. ${ }^{2}$ Por eso, aunque la estrategia de Didi-Huberman consiste muchas veces en atender a escritores marginales cuyas aportaciones habrían sido desdeñadas por la corriente principal de la disciplina a la que usualmente se les vincula y podría parecer que estudiar a estos autores es una recriminación casi moral contra una Academia endogámica que habría pasado por encima de los discursos más débiles, lo verdaderamente cierto es que se acude a ellos y a sus textos porque allí se encuentran indicaciones valiosas - y muchas veces no solo indicaciones, sino desarrollos más o menos coherentes - para establecer qué es una imagen y qué clase de tiempo lleva asociado.

Cuando uno se toma en serio el objeto de la Historia del Arte tiene que afirmar que las imágenes artísticas son como tumbas que hablan o, por lo menos, como tumbas en las que puede escucharse las palabras de los muertos. Una parte importante de la herencia cultural que cabe encontrar en las obras de arte, por decirlo un poco mejor, se ha depositado en ellas siguiendo un modelo fantasmal que vuelve imposible la tarea de describir dicha herencia como si se tratase de una más de sus coordenadas positivas - autor, fecha, técnica, iconografía, etc. Otra forma de expresar la

\footnotetext{
2 "Esta lógica de la efectividad parece tener una pertinencia limitada. Ciertamente, el límite no es nuevo, se marca desde siempre tanto en el idealismo antimarxista como en la tradición del «materialismo dialéctico». Pero dicho límite parece mejor demostrado que nunca por lo que ocurre hoy día de fantástico, fantasmático, «sintético», «protético», virtual, en el orden científico, y por tanto tecnomediático, y por tanto público y político." (Derrida, J, Espectros de Marx, Madrid, Trotta, 1995, p.77.) "Nos prohíben en adelante (más que nunca y de otro modo, pues no es absolutamente ni de pies a cabeza, nuevo) contraponer presencia a su representación, el tiempo real al tiempo diferido, la efectividad a su simulacro, lo vivo a lo no vivo..." (Ibídem, p.189).
} 
misma idea es decir que en ellas hay algo que no pertenece al tiempo en el que fueron producidas y que por tanto es anacrónico con respecto a ellas. Por eso, escribe Didi-Huberman, "es más válido reconocer la necesidad del anacronismo como una riqueza: parece interior a los objetos mismos - a las imágenes - cuya historia intentamos hacer. El anacronismo sería así, en una primera aproximación, el modo temporal de expresar la exuberancia, la complejidad, la sobre-determinación de las imágenes."3 Aceptar el anacronismo obliga empero a cuestionar todo un conjunto de certezas asentadas en la Historia del Arte acerca de aquello que subyace bajo un nombre semejante. No solo, como decimos, las certezas acerca de la naturaleza de las obras del Arte - el tema propio de un conocimiento que se dice Historia - sino también sobre la historicidad misma. ${ }^{4}$ La tradición historiográfica que va de Vasari a Panofsky y que incluye las diversas fundaciones y refundaciones de la historia del arte, tendría por trasfondo, desde esta perspectiva, una serie de presupuestos sobre qué son las cosas y las narraciones históricas, supuestos que habrían permanecido impensados para el saber institucionalizado. La apuesta de textos como Ante el tiempo y La imagen superviviente consistiría, de la mano de autores que, como Aby Warburg o Georges Bataille, llevaron a cabo su trabajo al margen de (y muchas veces en conflicto con) la institución universitaria, en poner de manifiesto y enjuiciar los prejuicios desde los que la investigación oficial se levanta.

"El objeto de la historia razonada del arte - había escrito nada menos que Winckelmann - es remontarse hasta su origen, seguir sus progresos y variaciones hasta su perfección y marcar su decadencia y caída hasta su extinción."5 Desde su moderna fundación como ciencia en el siglo XVIII la historia del arte ha consistido en la observación, la clasificación y el análisis de las obras artísticas que se producen a lo largo del tiempo. No se trata como en siglos anteriores de la simple com-

\footnotetext{
3 Didi-Huberman, G, Ante el tiempo. Historia del arte y anacronismo de las imágenes, Buenos Aires, Adriana Hidalgo Editora, 2011 pp. 38-39.

4 "[En la historia como proceso] existen modos de conexión que podemos llamar positivamente anacronías: acontecimientos, nociones, significados que toman el tiempo al revés, que hacen circular el sentido de una manera que escapa a toda contemporaneidad, a toda identidad del tiempo 'consigo mismo'. Una anacronía es una palabra, un acontecimiento, una secuencia significante fuera de 'su' tiempo, dotada por ello de la capacidad para definir orientaciones temporales inéditas, de asegurar el salto o la conexión de una línea temporal a otra. Y es por estas orientaciones, estos saltos, estas conexiones que es posible 'hacer' historia. La multiplicidad de líneas temporales, de sentidos propios del tiempo, incluidos en un 'mismo' tiempo, es la condición del proceder histórico. Tomarlo en cuenta de manera efectiva debería ser el punto de partida de una ciencia histórica menos preocupada por su respetabilidad histórica y más preocupada por lo que significa la palabra «historia»" Rancière, J., " Le concept de l'anachronisme et la verité de l'historien ", L'inactuel, 6 (1996), pp. 66.

5 Winckelmann, J, Reflexión sobre la imitación de las obras griegas en la pintura y la escultura, Madrid, Fondo de Cultura Económica de España, 2007, pp. XI-XII. Citado en Didi-Huberman, G., La imagen superviviente. Historia del arte y tiempo de los fantasmas según Aby Warburg, Madrid, Abada Editores, 2009, p.15.
} 
pilación de sus objetos sino que se esfuerza en determinar el periodo al que pertenecen, en ponerles fecha, y en esclarecer las relaciones que establecen con el resto de su época. Es decir, sigue con la mirada cada uno de los periodos artísticos, los tiempos del arte, para describir su nacimiento, sus variaciones y su decadencia. Toma las obras artísticas como documentos de la historia, los ordena y los estudia. Pero no se limita a esta tarea. También se interesa por las relaciones que se establecen entre objetos artísticos de periodos distintos. Desde este momento el anacronismo se vuelve un problema; mientras se tratara de un solo tiempo, de un único periodo no habría mezcla posible. Sin embargo cuando la historia del arte pretende hacerse cargo de las eventuales relaciones entre el arte o las obras de arte de dos etapas distintas, el anacronismo es condenado como el error más grave del historiador: no se puede transgredir la secuencia cronológica de los hechos - hay que "evitar el pecado de los pecados - el pecado entre todos irremisible: el anacronismo" como escribía Lucien Febvre al comienzo de su Rabelais. No obstante, se dirá, puesto que la intromisión es inevitable, no solo porque la relación entre acontecimientos de épocas diversas se fija desde la del historiador, sino más aún porque se trata justamente de explicar la relación de una época con otra, el anacronismo tiene que ser controlado, es decir, tiene que emplearse bajo las categorías adecuadas y con la prudencia debida para mantener tanto la linealidad de la historia como el carácter de hecho de, en este caso, la imagen artística. Así, los efectos de un periodo sobre otro se han planteado unas veces en términos de fuentes artísticas, otras, de un modo más formalista hablando de influencias, como restos materiales, también conforme a tradiciones iconográficas, a menudo desde la referencia a las normas estilísticas anteriores, a géneros artísticos que se han mantenido inalterables, etc. En todos los casos formas de permanencia estable y más o menos explícita de la tradición. Mediante estas categorías la historia del arte se asegura de que el pasado de las obras sea pensable no tanto como pasado sino como algo que pueda ser contemporáneo de la obra misma, es decir, como algo que para la obra y su creador pudiese estar presente. Incluso Winckelmann, para quien el arte de la Antigüedad (en el que se había alcanzado el ideal de belleza) se había perdido irremediablemente y quien parecía reconocer un abismo insalvable entre su época y la grandeza de los antiguos, veía, sin embargo, en la práctica del artista neoclásico una forma de imitación capaz de tender un puente por encima de esa pérdida. "[Esa imitación] crea entre el original y la copia un vínculo tal que el ideal, 'la esencia del arte', puede en cierto modo revivir, atravesar el tiempo. Es gracias a la imitación como la 'ausencia categórica' del arte griego [...] se hace susceptible de un renacimiento, e incluso de una presencia intensa. Porque, desde luego, es de presencia y de presente de lo que se trata: el presente de la imitación hace 'revivir un origen perdido' y restituye así al origen una presencia activa, actual." $6 \mathrm{El}$ ideal de belleza griego, como corresponde

6 Didi-Huberman 2009, op.cit (nota 5), p. 21. 
a todo ideal, es contemporáneo de cualquier artista y de cualquier obra de arte, por lo que el historiador puede referirse a él sin concurrir en anacronismos. Las formas atenuadas de permanencia - los géneros, las tradiciones iconográficas... - no son en esto diferentes; al ser contemporáneas de artista y obra también esquivan el anacronismo. Puestas así las cosas el pasado de la obra o bien no es en realidad anterior a ella sino que pertenece a su presente ${ }^{7} \mathrm{o}$ bien se ha perdido irremediablemente. Si ocurre esto último entonces jamás volverá a ser convocado como potencia efectiva: "su existencia (aunque sea espectral), su supervivencia o su resurrección ni tan siquiera se plantearán" 8 .

Según Didi-Huberman, la obra de Aby Warburg es el lugar al que habría que remontarse para encontrar las primeras formulaciones decisivas relacionadas con el trastrocamiento de este paradigma temporal ligado a la ontología de la presencia. Es un motivo recurrente en sus estudios sobre el Renacimiento el que aparezcan unidos elementos anacrónicos y heterogéneos a la hora de analizar elementos visuales. En un artículo intitulado El punto de vista anacrónico, Didi-Huberman ilustra a lo que se refiere con un ejemplo tomado de los Ensayos florentinos de Warburg: en los rostros pintados por Ghirlandaio, cuya belleza expresiva era propia de su época, Warburg encontraba cierta impureza que estaba vinculada con los procedimientos de vaciado de las antiguas máscaras funerarias romanas. Una impureza que no solo dejaba ver el yeso frío de las técnicas de impresión de la antigua Roma, sino también la tierra cocida de los etruscos y la cera votiva de las devociones medievales. Si estos rasgos son al menos una parte del Renacimiento de él no se podrá seguir diciendo que es un retorno a la pureza antigua porque estaría henchido, esta sería la tesis de Warburg, de impurezas reminiscentes. "Todas las épocas se trastornan, se contradicen como otros tantos síntomas en estas imágenes de las que Warburg debía sacar, más allá de esa demasiado apacible 'tradición icológica' que sabemos que le debemos, un nuevo modelo de temporalidad - un modelo contemporáneo y próximo al establecido por Freud - un modelo complejo de lo que él llamaba 'supervivencia' (Nachleben)."9 Este modelo, como anunciábamos más arriba, debería hacer pensable la manera en que toda una herencia cultural se ha transmi-

\footnotetext{
7 Es manifiesto, por lo menos desde Heidegger, que el modo común como accedemos al tiempo consiste en subordinar el pasado y el futuro a la forma del presente. También que este tratamiento es constante a lo largo de la Historia de la Filosofía. El pasado sería un ahora que ya no es y el futuro uno que todavía no ha llegado. Gran parte del pensamiento francés contemporáneo ha mostrado las dificultades que esta metafísica de la presencia o régimen de la representación suscitan a la hora de pensar ciertos fenómenos - por ejemplo el movimiento o devenir. Sobre los fundamentos y los problemas de dichos intentos de escapar del primado de la presencia puede leerse el ya clásico artículo de José Luis Pardo, «Las desventuras de la potencia (Otras consideraciones inactuales)» en Nunca fue tan hermosa la basura, Madrid, Galaxia Gutemberg, 2010, pp. 319-348.

8 Didi-Huberman 2009, op.cit (nota 5), p.15.

9 Didi-Huberman, G, «El punto de vista anacrónico» en Revista de Occidente, 213 (1999), p.28.
} 
tido y se ha depositado en las imágenes artísticas - en su memoria. Reconocería el derecho de las imágenes - y por esto y no por otra cosa Didi-Huberman puede hablar de hacer justicia en la Historia del Arte - a ser de hecho extremadamente complejas, admitiría que ellas mismas puedan estar constituidas por relaciones y determinaciones que desbordan su tiempo, o para expresarlo mejor, que el tiempo que ellas son - el tiempo de las imágenes - consiste en un extraño entrelazamiento de tiempos anacrónicos.

Puesto que con Warburg cambia nuestra manera de estar ante una imagen, lo que ahora significa estar ante un tiempo complejo, el pensamiento del arte y el pensamiento de la historia, escribe Didi-Huberman, experimentan un giro decisivo. Aceptar este planteamiento no solo supone la sustitución del modelo ideal de los renacimientos y las imitaciones que se repite por doquier a cambio de otra lógica más amplia - ¿pero en qué consiste? ¿qué lógica, qué tiempo para los fantasmas en definitiva, sería ésta que no estaría sometida a la transmisión que supone la imitación de las obras antiguas por obras más recientes? ¿a esta lógica le correspondería o no un logos, un discurso? ¿se podrá alguna vez empezar a responder a estas preguntas? - también transforma el trabajo mismo de quien tiene que estudiar y contar la historia. La presencia del pasado en la obra de arte no puede pensarse mediante un modelo lineal o causal, sea este el que sea, porque harían de él un presente para la obra. Se habrá de precisar el modo en que los tiempos están ahí: "estratos, bloques híbridos, rizomas, complejidades específicas, retornos a menudo inesperados y objetivos siempre desbaratados" 10 Ahora bien, lo que se deposita en la imagen adoptando, por ejemplo, la (no-)estructura propia del rizoma no proviene punto de partida del proyecto warburguiano - en exclusiva ni la mayor parte de las veces de instancias pertenecientes a lo que usualmente se entiende que son los objetos de la Historia del Arte. 11 Warburg obligaba al historiador a convertirse en antropólogo si era necesario - y lo era si quería, por ejemplo, atender a las máscaras mortuorias romanas. Sostuvo que para pensar las imágenes artísticas era necesaria una aproximación conjunta de la antropología, la etnología, la mitología, la psicología y la biología, porque no había nada que exigiera que la única comunicación relevante para los problemas de la historia del arte fuera la que establecerían las imágenes con los elementos, por así decir, estéticos de la tradición.

Hasta aquí hemos intentado esbozar un par de rasgos que deberían caracterizar el modelo de tiempo fantasmal prometido. Al contrario de lo que ocurre en los

10 Didi-Huberman 2009, op.cit (nota 5), pp. 24-25.

11 "Aby Warburg - escribe Giorgio Agamben - conservó durante toda su vida una honesta repugnancia frente a la historia del arte estetizante." Dado que para Warburg la imagen consistía en una condensación particularmente significativa de lo que es una cultura, Agamben renuncia incluso a subsumir su quehacer dentro de la Historia del Arte y prefiere concebirlo como los primeros pasos de una Ciencia sin nombre. Agamben, G, «Aby Warburg y la ciencia sin nombre» en La potencia del pensamiento, Barcelona, Anagrama, 2008, pp. 129-30. 
modelos de transmisión empleados tradicionalmente por la academia y que, como hemos señalado, solo reconocen presencias repetidas y ausencias en el tiempo, (i) los restos del pasado inscritos en las imágenes serían para Didi-Huberman y Warburg como fantasmas. Aunque en gran medida el tiempo los haya destruido y apenas sean visibles siguen existiendo de un modo no completamente pleno. Estas huellas (ii) no las habría generado exclusivamente el arte de los periodos anteriores sino que podrían haberse depositado desde instancias diversas de la cultura y, por tanto, hacerlas visibles podría requerir un trabajo más global que el del historiador del arte tradicional. Antes de tratar de reconstruir de un modo un poco más amplio la primera de estas características acudiendo al concepto warburguiano de Nachleben, quisiéramos ilustrar algunas de las consecuencias de la segunda a través de una breve reconstrucción de los análisis que Didi-Huberman dedica a la obra de dos autores que considera próximos a Aby Warburg: Edward B. Tylor y Walter Benjamin.

¿En qué se refleja la mayor amplitud del proceder historiográfico demandado por Warburg? Por un lado, ya lo hemos dicho, en la necesidad, para dar cuenta de la imagen, de una investigación conjunta de los saberes culturales - lo que más de uno querría hoy denominar una tarea interdisciplinar. En segundo lugar, además de serlo por abordar cada imagen desde un mayor número de perspectivas, la historia del arte warburguiana es más amplia, simple y llanamente, porque analiza más cosas. Amplitud no significa entonces mayor abstracción o mayor generalidad, sino todo lo contrario: el historiador debe prestar atención a todos y cada uno de los elementos - propios de la obra o exteriores a ella - que pudieran determinarla no importa en qué medida porque hasta los detalles aparentemente más insignificantes podrían indicar algo relevante acerca de la imagen. "Así, la notificación de un pago por un exvoto realizado en 1481 sobre el rostro mismo del donante, o bien las últimas voluntades de un burgués florentino, se convertirán a sus ojos en una verdadera materia - materia moviente y sin límite - para reinventar la historia de Renacimiento"12. Hace falta entonces, piensa Didi-Huberman, multiplicar los puntos de vista, los modos de acercamiento, las competencias. Cuando las huellas del pasado se encuentran como él dice en un horóscopo, en una carta comercial, en una guirnalda de flores (esas de las que deriva el sobrenombre de Ghirlandaio), en el detalle de una moda de vestir, un bucle de cinturón o una particular circunvolución de un moño femenino entonces el historiador del arte se ve desbordado. Tiene que hacerse infinitamente paciente, estar siempre dispuesto a ampliar los límites de su investigación y a complementarla con otros documentos (antropológicos, mitológi$\cos$, etnológicos...) a los que hasta entonces no había atendido. El resultado es entonces una historia fantasmal. "Warburg escribe que con 'los documentos de

12 Didi-Huberman 2009, op.cit (nota 5), p. 36. 
archivo descifrados', se trata de 'restituir timbres de voz inaudibles', voces de desaparecidos, voces sin embargo ocultas, replegadas todavía en la simple grafía o en los giros particulares de un diario íntimo del Quattrocento."13 Loca exigencia, dirá más tarde al hablar del Atlas de Warburg Mnemosyne, pensar cada imagen en relación con todas las demás; loca consecuencia que este pensamiento haga surgir siempre otras imágenes, otras relaciones y otros problemas, ocultos hasta entonces pero no menos importantes.

La referencia al trabajo del etnólogo y antropólogo británico Edward B. Tylor "cuyo carácter de fuente para Warburg es estudiado al comienzo de La imagen superviviente" puede ilustrar este doble aspecto - en cuanto a las perspectivas y en cuanto a los objetos - de la dicha amplitud. El punto de contacto entre Warburg y Tylor consiste, nos dice Didi-Huberman, en el establecimiento de un vínculo particular entre historia y antropología. El problema fundamental de la ciencia de la cultura (sciencie of culture, la ciencia buscada del antropólogo) residía para Tylor en la imposibilidad de explicar su desarrollo con leyes de evolución como las que emplean las ciencias naturales. Al comienzo de Primitive Culture Tylor exigía en primer lugar una investigación histórica de las culturas, renunciando así a la intemporalidad que con frecuencia se ha atribuido a la antropología, lo que le obligaba a hablar de su desarrollo. En segundo lugar, especificaba que los dos modelos disponibles para elaborar un discurso sobre él - lo que llama "teoría del progreso" y "teoría de la degeneración" - no son funcionales tomados por sí mismos sino que tienen que ser relacionados dialécticamente entre sí para referirse correctamente al desarrollo de las culturas. "El resultado será un nudo de tiempo difícil de descifrar porque en él se cruzan una y otra vez movimientos de evolución y movimientos que resisten la evolución."14 Primitive Culture se publicó en 1871, pero algunos años antes Tylor había publicado Anahuac - el diario de su viaje por México en 1856 -, en el que por primera vez aparecía aquello que después llamaría survival, supervivencia, y que actuaría como diferencial entre estos dos tipos de progresión temporal contradictorios. En el diario de viaje del antropólogo asistimos a su continuo asombro frente a la realidad mexicana. La extrañeza de Tylor, tal como la describe Didi-Huberman, lo sería ante el hecho de que en un mismo acontecimiento, en el mismo lugar y en el mismo momento, se pudieran mezclar cosas pasadas y cosas presentes; sorpresa por tanto porque tales acontecimientos fueran nudos de anacronismos. "Así, las fiestas de la Semana Santa en México actualizan conmemoraciones heterogéneas, mitad cristianas mitad paganas; así, el mercado indio de Grande actualiza un sistema de numeración que Tylor creía que no se podía ya encontrar más que en los manuscritos precolombinos; así, los ornamentos de los antiguos

\footnotetext{
13 Ibidem. p. 36.
}

14 Ibidem. p. 47. 
cuchillos sacrificiales están próximos a los de las espuelas de los vaqueros mexicanos"15 Por eso el etnólogo debe hacerse historiador. Y por eso el historiador del arte deberá hacerse etnólogo. El trabajo del antropólogo cuya amplitud es de tipo horizontal - pues se admite habitualmente que una cultura es harto compleja y que puede ser estudiada desde diversas disciplinas - descubre que las realidades a las que se enfrenta tienen también una historia enrevesada - complejidad vertical de los tiempos estratificados en su interior -, lo que le obliga a atender a su dimensión temporal.16 El ejemplo mexicano tiene además otra virtud. La permanencia del pasado en el presente había podido ser expresada por ciertas antropologías filosóficas del siglo XIX en términos de rasgos globales o arquetípicos de la cultura en cuestión, como la esencia de la cultura de este pueblo o aquel otro. Sin embargo, los rasgos culturales que acabamos de mencionar, los cuchillos, las espuelas, las procesiones y los sistemas de numeración no pueden ser calificados como hechos esenciales de ninguna cultura.

Se me podrá quizá reprochar que, en el curso de este estudio dedicado a lo que yo he llamado supervivencias del antiguo estado social y que son restos debilitados de la cultura de las primeras épocas, [...] haya elegido tantos ejemplos referidos a cosas fuera de uso, sin valor, frívolas e incluso de un absurdo que presenta peligros y malas influencias. Pero he elegido este género de pruebas de un modo intencionado" (Tylor, Primitive Culture, p.142)

Progreso decadencia, supervivencia, renacimiento, modificación son otras tantas formas según las cuales se relacionan las partes de la red compleja de la civilización. Basta echar un vistazo a los detalles triviales de nuestra vida cotidiana para darnos cuenta de en qué medida somos creadores y en qué medida no hacemos sino transmitir y modificar la herencia de los siglos anteriores. El que no conoce más que su propio tiempo es incapaz de explicarse lo que ve tan sólo mirando en su habitación. Allí están la madreselva de Asiria, la flor de lis de Anjou; una cornisa con un marco a la griega que rodea el techo; el estilo Luis XIV y el estilo Renacimiento, de la misma familia, se reparten la decoración del espejo. Transformados, transportados o mutilados, estos elementos del

\footnotetext{
15 Ibídem. p. 48.

${ }^{16}$ Con el historiador del arte ocurrirá la operación inversa: al investigar los tiempos que se entrelazan en las obras de arte de cualquier periodo encontrará que su procedencia es completamente heterogénea y deberá ampliar las disciplinas en las que se apoya. El orden empírico de la investigación seguramente no sea este. El historiador del arte primero supondrá que en la obra de arte hay residuos, por ejemplo, de la religión pagana, después ampliará su perspectiva hasta incluir los estudios sobre la mitología y descubrirá que en la obra hay inscritos tiempos cuyo origen cabe situar en la mencionada religión pagana. Ahora bien, lo importante es que cuando esto ha ocurrido por primera vez el investigador está legitimado a extender casi ilimitadamente esta tipo de operación. Si encuentra algo relevante - pero ¿qué aquí es relevante? cabría preguntar - la proliferación desmedida de perspectivas es gesto válido para el antropólogo-historiador.
} 
arte conservan todavía la huella de su historia; y si, sobre objetos más antiguos, la historia es todavía más difícil de leer, no debemos concluir de ello que no la tengan. ${ }^{17}$

Para Tylor, como después lo será para Warburg, la permanencia de las formas antiguas en el presente no se expresa ni a través de grandes hechos ni mucho menos a través de universales transespocales, sino mediante estas cosas fuera de uso, frívolas y triviales que no son advertidas la mayor parte de las veces por la mirada del estudioso. Pequeños detalles hacia los que se han desplazado ciertos rasgos del pasado y que a causa de su pequeñez han podido, por así decir, pasar desapercibidos y conservarse. Las supervivencias existen principalmente en estas pequeñas huellas desplazadas del camino principal. Por eso es que Tylor se interesa por los juegos infantiles - ¿qué habría más trivial para una cultura que los juegos de sus niños? - donde reconoce viejas prácticas entonces muy serias de guerra o de adivinación: el arco y la flecha, las tabas y los naipes, habrán sobrevivido en algunos de estos juegos a costa de perder su significación original. Warburg hará algo parecido, por ejemplo, al interrogar las prácticas festivas del Renacimiento. Se notará que esta manera de hacer historia-antropología está en las antípodas de aquella grandiosa historia universal del idealismo alemán - y acaso por eso en algún momento Didi-Huberman subraya que la temporalidad que trata de re-elaborar es completamente opuesta a la que cabría sustraer de la filosofía de la historia de Hegel.18

Este gusto por las cosas insignificantes propio de Tylor se manifiesta todavía con mayor fuerza en la obra de Walter Benjamin. En unas pocas páginas del segundo capítulo de Ante el tiempo, intitulado La imagen-malicia, Didi-Huberman describe la simpatía entre el trabajo de Benjamin, el trapero de la historia, y el de Warburg. Esta proximidad se funda en la común apertura del campo de objetos de la que nos venimos ocupando. Acerca de ella Didi-Huberman escribe: "si, como señala Benjamin, 'la imaginación desborda por todos lados los límites del arte', eso quiere decir que Warburg tenía mucha razón en apelar, más allá de la historia del arte 'autónoma', a una verdadera antropología de las imágenes capaz de analizar los aspectos fundamentales pero también específicos - incluso formales - de esos 'desbordamientos."'19 La tercera de las Tesis sobre el concepto de historia comen-

17 Tylor, E. Primitive Culture, Londres, Murray, 1871. (p.142 y p.16) Pasajes citados en DidiHuberman, 2009, (nota 5) pp. 49-52).

18 "Seleccionar esos detalles [las peculiaridades de los individuos histórico-universales] sólo puede hacerlo un historiador inteligente y, viceversa, gran cantidad de detalles de otra clase es material superfluo cuya cuidadosa recolección oscurece y perjudica los objetos merecedores de historia; los rasgos esenciales de un espíritu y de su tiempo están siempre contenidos en los grandes acontecimientos [...]Entretejer las pequeñeces particulares de la época y de las personas con la representación de los intereses generales, so capa del interés de la llamada verdad [del relato], no peca solamente contra el buen juicio y el buen gusto, sino contra el concepto de verdad objetiva en cuyo sentido sólo lo sustancial es verdadero para el espíritu.” (Hegel, Enciclopedia de las ciencias filosóficas, §549).

19 Didi-Huberman 2011, op.cit. (nota 3), p. 147. 
zaba prescribiendo que no se diera nada por perdido para la historia de entre todo aquello que alguna vez hubiese acontecido. Para Benjamin el auténtico historiador debía narrar los acontecimientos sin distinguir entre los grandes y los pequeños y algo así es lo que él mismo habría intentado en El libro de los Pasajes. Lo que los ilustres autores de la filosofía de la Historia podían considerar como perder el tiempo con lo inesencial, para Benjamin era una parte central de su trabajo. Los mismos pasajes de París, los dos millones y medio de remaches de la torre Eiffel, también la moda del siglo XIX, los sistemas de iluminación de la época, figuras como la del flâneur y la prostituta, los escaparates, las barajas de los garitos... todo estaba destinado a convertirse en sus manos en el soporte de una cuidadosa crónica que no pudo completar. La historia materialista de Benjamin se ejerce a través de la recopilación, el montaje y la utilización de los andrajos (die Lumpen) y los desechos (den Abfall) del pasado. ¿Pero a qué obedece la insistencia benjaminiana de fijar la historia en sus cristalizaciones más humildes? Pues bien, a que Benjamin piensa aunque seguramente sea Didi-Huberman quien haga de estas indicaciones un punto central de su pensamiento - que el pasado no es un hecho objetivo sino un hecho de memoria, esto es, un hecho psíquico. Benjamin "comprendió que no había historia posible sin teorías del 'inconsciente del tiempo': las supervivencias exigen del historiador algo así como una interpretación de los sueños."20 La lógica de las supervivencias sería parecida a la del inconsciente o sería ella misma una lógica inconsciente. Lo que sobrevive sólo llegaría a nosotros evitando convertirse en el tema explícito de los acontecimientos históricos, como si de lo que se tratara fuera de esquivar a la conciencia (histórica) que en cuanto los reconociera trataría de evitarlos. Para sortear dicho rechazo buscarían depositarse en los elementos más ornamentales, en los vestigios y despojos irrelevantes de la historia. Este sería el segundo punto de contacto entre Benjamin y Warburg pues, aunque la obra de éste último no tiene a Freud como una de sus fuentes indiscutibles - la expresión es de DidiHuberman - como sí tenía a Tylor (y a Nietzsche, y a Darwin, y a Burckhardt...), su pensamiento, el pensamiento de Warburg apuntaría a una lógica del síntoma de tipo freudiano. Benjamin, quien sí prestó la debida atención al psicoanálisis, lo habría introducido como parte importante de su trabajo. En algún lugar de los Pasajes, Benjamin había escrito que hay un saber-todavía-no-consciente del pasado (Noch-nich-bewusstes-Wissen vom Gewesen) cuyo avance tiene, en realidad, la estructura de un despertar y que era justamente de esta estructura de la cual la historia debía ocuparse. "La novedad de la historia benjaminiana consiste en que resueltamente hizo del inconsciente un objeto para la historia." 21 Aquello a lo que se enfrenta el historiador materialista sería un pasado de orden psíquico (una memoria) constituido por diversos ritmos: el ritmo de los sueños, de los síntomas o de los

20 Ibidem. p. 147.

21 Ibidem. p. 176. 
fantasmas, el ritmo de las represiones y del retorno de lo reprimido, el ritmo de las latencias y las crisis, etc. Si este es el objeto de su trabajo, el historiador debería, nos dice Didi-Huberman, "adoptar la escucha flotante del psicoanalista atento a las redes de detalles, a las tramas sensibles formadas por las relaciones entre las cosas." 22 Por último, y estaría sería la tercera de las simpatías entre Warburg y Benjamin, ambos habrían puesto a la imagen (Bild) en el centro neurálgico de la investigación histórica y habrían tratado de elaborar a partir de ella, de lo que ella es, a saber, un nudo de tiempo, nuevos modelos de temporalidad que ya no la reducirían a un punto sobre la línea cronológica, a una causa o un efecto. Lo que Aby Warburg habría tratado de captar a partir de conceptos como Polarität, Pathosformel y Nachleben, Walter Benjamin, piensa Didi-Huberman, "terminó de captarlo en términos de 'dialéctica' y de 'imagen dialéctica' (Dialektik, dialektische Bild)."23

El concepto de imagen dialéctica aparece bosquejado en los fragmentos del Libro de los Pasajes ${ }^{24}$ recogidos bajo el epígrafe Teoría del conocimiento, teoría del progreso. No es este el lugar - tampoco habría espacio suficiente - para exponer las dificultades hermenéuticas que suscita un texto como el Libro de los Pasajes, por lo demás inacabado. Baste indicar que por lo que hace a la noción de imagen dialéctica las hay. Se la aborda siempre en fragmentos dispersos y oscuros, donde en rigor solo se dan algunas indicaciones acerca de su significado y, lo que seguramente sea peor, en los que parece que la imagen dialéctica no tiene nada que ver con las obras de arte tal como Didi- Huberman quisiera sostener. Una imagen dialéctica es en primer lugar una forma de disponer el objeto histórico (N 9a, 4) en donde lo que ha sido se une como en un relámpago al ahora en una constelación (N2a, 3). Este tipo de imágenes serían para Benjamin capaces de proporcionar un conocimiento acerca de aquello sobre lo que se elaboran, en este caso sobre el Paris del siglo XIX, sin reducir lo que las constituye a momentos de una narración histórico-historicista al uso, esto es, a elementos de una serie ordenada de causas y efectos. Frente al movimiento hacia delante - progreso - de la historia que toda narración implica, Benjamin prefería hablar de imágenes, de dialéctica en reposo, de relámpagos y fulguraciones. Se trata siempre de formas inmediatas opuestas al relato en las que se muestra rápidamente la verdad del pasado, lo que él denominaba su índice histórico. Toda circunstancia histórica que se expone mediante una imagen dialéctica, escribe, se polariza convirtiéndose en un campo de fuerzas en el que tiene lugar el conflicto entre su historia previa y su historia posterior (N7a, 1). Benjamin estaba convencido de que para pensar la historia se necesitaba una lógi-

\footnotetext{
22 Ibidem. p. 156.

23 Ibidem. p. 143.

24 Benjamin, W, Libro de los Pasajes, Madrid, Akal, 2005. Todas las citas están extraídas del legajo N. Se indica cada fragmento entre paréntesis en el cuerpo del texto.
} 
ca visual, no lineal. La técnica del montaje (que es típicamente visual) aplicada a la historia debía poder construir objetos históricos en los que el presente y pasado estuvieran entretejidos, en los que el pasado llegara al presente y lo iluminara de un modo especial. De eso se trataba después de todo con la obra de los Pasajes.

Los objetos del siglo XIX debían volverse visibles en tanto orígenes del presente [unión pues de presente y pasado], simultáneamente todo supuesto acerca del progreso debía ser rechazado. [...] Como aprehensión inmediata, cuasi mística, la imagen dialéctica era intuitiva. Como ‘construcción' filosófica no lo era. El laborioso y detallado estudio de los textos, el cuidadoso inventario de los fragmentos extraídos y el uso planificado en 'constelaciones' deliberadamente construidas eran todos procedimientos reflexivos y rigurosos que Benjamin consideraba necesarios para volver visible una imagen de la verdad que la ficción de la escritura convencional de la historia había ocultado. 25

No sé si se percibe la dificultad. Es el montaje de fragmentos el que constituye la imagen dialéctica en la que se hace legible en un instante presente y actual, el tiempo histórico al que los elementos de la imagen pertenecen; allí se hace legible también su conexión con el tiempo histórico en el que se la elabora. En la imagen estaría contenido un pasado que solo en ella y a partir de ella podría ser conocido en el presente sin la mediación de un relato. Una imagen dialéctica tal y como la presenta Benjamin es por tanto una construcción del historiador, una forma de disponer elementos que devuelve la verdad histórica de una época - y que, sí, implica, explicita o, por lo menos, tiene que ver con un modelo temporal del tipo que DidiHuberman busca. Pero en cualquier caso el pasado no estaría sin más en los hechos mismos y tampoco, como él quisiera afirmar, en las obras de arte. Dicho de otra manera: la imagen dialéctica es según Benjamin una herramienta del historiador, una manera de disponer (una configuración, que es otra traducción posible para el término Bild que se vierte como imagen) los objetos del conocimiento histórico y no el objeto mismo. Nunca se podrá, como a menudo hace Didi-Huberman - desde el mismo título La imagen superviviente - dar por sentado que las obras de arte son un tipo de imágenes dialécticas. Lo que sí es posible, fecundo y, con toda probabilidad, aquello que Didi-Huberman debe estar queriendo expresar al recordar estos pasajes de Benjamin, es que una disposición (Bild) dialéctica de las obras de arte es el único modo de hacer visible el pasado sedimentado en ellas, su condición esencialmente anacrónica y la mezcla de tiempos que las constituyen.

Cualquier lector honesto de Benjamin sabe que sus textos son enormemente herméticos y que están lejos de proporcionar un concepto acabado de nada. Con la imagen dialéctica ocurre eso exactamente. Lo que hemos llegado a entender de ella

\footnotetext{
25 Buck-Morss, S, Dialéctica de la mirada. Walter Benjamin y el proyecto de los Pasajes, Madrid, La Balsa de la Medusa ed, Visor, 1995, pp. 244-246.
} 
no solo nos parece interesante, sino muy fructífero y lúcido, pero pensamos que está muy lejos de terminar de captar la relación entre la imagen y la historia - y mucho más lejos de precisar qué sea el tiempo de los fantasmas. 26 Esto que ocurre con Benjamin no es un problema puntual, sino que es parte de una de las mayores dificultades que suscita la lectura de Didi-Huberman y que estaríamos tentados a llamar el problema de los homenajes. Si los textos de Benjamin son herméticos, tanto o más lo son los del resto de autores favoritos de Didi-Huberman: Georges Bataille, Friedrich Nietzsche, Carl Einstein, Sigmund Freud... Los libros de los que nos venimos ocupando, Ante el tiempo y La imagen superviviente, son en rigor recopilaciones inteligentemente ordenadas de artículos que ya habían sido publicados. La pretensión original de estos últimos parecía ser anunciar la importancia de estos pensadores para, como ya hemos dicho, refundar algunos de los presupuestos más importantes de ese saber sobre las imágenes que es la Historia del Arte. Quizá debido a la limitada extensión de un artículo de revista, en ellos esta importancia solo queda apuntada. Uno podría haber esperado que estas indicaciones se desplegaran al incorporar los artículos a un libro, pero el papel de estos pensadores nunca queda concretado - e intuimos lo que pronto se nos dirá: que no se puede concretar ni hacer explícito, que no se pueden sentar los presupuestos de nuevo, que la Historia del Arte tal como la concibe Didi-Huberman está siempre por fundar - sino que ocurre más bien lo contrario. Las exigencias del formato se mantienen y en los momentos cruciales se sigue recurriendo a la mera paráfrasis de sus textos, de los de Bataille, Nietzsche y Warburg, preservando de este modo su oscuridad. Y eso en el mejor de los casos. Tristemente la mayoría de las veces se sugiere que dichas oscuridades se resolverían atendiendo a lo que otro autor dice sobre el tema - por eso se habrán recogido los diversos artículos en un mismo volumen - y solo se consigue que una oscuridad acabe remitiendo a otra: así para interpretar a Warburg hay que comprometerse con los conceptos del psicoanálisis (que ya es suficientemente complejo por sí solo) y para entender a Carl Einstein hay que hacerlo con el erotismo de Bataille. Este entramado añade a los problemas de interpretación de cada uno de estos autores - se suele decir, por ejemplo, que a Nietzsche uno nunca está seguro de haberlo comprendido, que siempre se nos escapa - el de la coherencia entre

\footnotetext{
26 Algo parecido ocurre con las referencias a Sigmund Freud y al psicoanálisis. Didi-Huberman en numerosas ocasiones afirma que el tiempo que él busca es el del inconsciente, que la sobre-determinación temporal de las obras de arte debe ser explicada en términos de síntoma en sentido freudiano. Estas referencias son la mayoría de las veces meramente programáticas y nunca van seguidas de una elaboración mayor. Por supuesto nunca se indica, que nosotros sepamos, en qué consistiría el psicoanálisis de una cultura o un periodo histórico, ni se describe con un mínimo de rigor en qué puede consistir tratar psicoanalíticamente con la Historia del Arte. Las referencias a Freud se multiplican asimismo a partir de citas en las que diversos autores emplean términos que sugieren una proximidad con algo así con la teoría psicoanalítica. Pensamos que si alguien quisiera tomar como esenciales las referencias al psicoanálisis no sabría cómo hacerlo.
} 
ellos. Si esto fuera poco, las referencias y los guiños no a los autores sobre los que se escribe, sino a autores más próximos y en principio afines son bastante numerosas. La apuesta de ambos trabajos - en los que se homenajea explícitamente a Deleuze - se describe unas veces como una arqueología de los modelos de tiempo de la historia de arte, otras como su deconstrucción. ${ }^{27}$ Uno quizá querría leer estos gestos como declaraciones de compromisos teóricos con autores como Derrida, Deleuze y Foucault quienes son, a pesar de algunos de sus más fieles lectores, mucho más académicos y mucho más sistemáticos que Bataille, Benjamin y compañía. Pero, de nuevo, es imposible medir hasta dónde llegaría ese compromiso y solo cabe entender tales afirmaciones como homenajes al espíritu crítico (es decir, no a la letra) de sus planteamientos.

Pese a ello, cuando la propuesta teórica de Didi-Huberman se articula alrededor de la noción de supervivencia parece inteligible por sí misma. Es decir, los problemas que exigen la elaboración de este concepto están bien definidos así como los rasgos mínimos que deberían caracterizarlo. Su validez se mantiene, pensamos, con independencia de los textos y autores a los que por economía haya sido y sea necesario recurrir para su formulación. En lo que sigue intentaremos dar una descripción mínima del concepto de Nachleben y procuraremos señalar los caminos que esta noción y aquellas a las que está esencialmente vinculada dejan abiertos.

Los supervivientes y los que sobreviven no son los mismos. Los primeros aparecen después de accidentes, naufragios, atentados terroristas y catástrofes naturales. Son las personas que cuando los demás mueren y hay suerte continúan con vida, los que después se convierten en los protagonistas de esas trágicas historias - que si son lo bastante importantes entrarán en la Historia - y de quienes se dice que han esquivado a la muerte. Los segundos son aquellos que, a veces desamparados y casi siempre humildes, viven con escasos medios y en condiciones adversas. A estos últimos no se los llama supervivientes - no tienen nada de súper - pero sobreviven también. Los traperos, los mendigos, las amas de casa proletarias y sus niños, los ancianos y los enfermos de gravedad forman este grupo heterogéneo. De ellos se dicen que no tienen donde caerse muertos, que un poco ya lo están o que tienen un pie en la tumba. Despojos de la ciudad industrial, son ignorados sistemáticamente

27 Difícil matrimonio el de Derrida y Foucault - cualquiera que se haya aproximado a sus filosofías sabe de la incompatibilidad de sus planteamientos. Incompatibilidad que por otro lado ellos mismos hicieron explícita. Puede seguirse la interesante discusión en Derrida, J., « Cogito e historia de la locura » en La escritura y la diferencia, Barcelona, Anthropos, 1989 y Foucault, M., « Mi cuerpo, ese papel, ese fuego » en Historia de la locura en la época clásica (vol.2), México, Fondo de Cultura Económica, 2010. En la práctica de esta extrañamente declarada arqueología Didi-Huberman no descubre ninguna discontinuidad entre modelos de tiempo (no se habla, ni se puede hablar, del modelo de tiempo propio la época clásica o la moderna, por ejemplo) sino que se constata un tipo de temporalidad (lineal, cronológica, causal) que aparece sistemáticamente en cada nueva fundación de la disciplina. Es por eso que comenzamos aproximando su proyecto a las tesis de Jacques Derrida. 
por las grandes Historias escritas por y para dirigentes carismáticos o miembros del partido revolucionario. No sobreviven a la muerte de los demás, sino a la suya propia. A lo designado por el concepto de Nachleben le ocurre algo parecido: no es lo que sobrevive a esta o aquella catástrofe de la historia - por ejemplo, no se trata del espíritu reaccionario que perdura gracias a ciertos políticos o a ciertos artistas - es algo que está desde siempre, o al menos desde un momento imposible de determinar, a punto de desaparecer, casi muerto. "La forma superviviente, en el sentido de Warburg, no sobrevive triunfalmente a la muerte de sus concurrentes. Muy al contrario, sobrevive sintomática y fantasmalmente, a su propia muerte: desapareciendo en un momento dado de la historia, reapareciendo más tarde en un momento en que quizás ya no se la esperaba." 28 De las supervivencias habría que decir que existen con un pie en este mundo y un pie en el otro; como los fantasmas, las supervivencias están ahí de un modo que no es completamente vida ni completamente muerte, ni presencia ni ausencia.

Como ya hemos señalado Aby Warburg elaboró la noción de Nachleben en un marco histórico concreto que constituye el ámbito casi exclusivo de sus estudios publicados: el Renacimiento, el italiano en primer lugar y posteriormente el flamenco y el alemán. ¿Por qué vías ejerció el pasado su influencia en el periodo renacentista? Esta sería la pregunta principal a la que el concepto de supervivencia vendría a dar respuesta. Ya sabemos que la influencia en cuestión no puede ser pensada, como el propio término Renacimiento sugiere, a modo de un puro y simple retorno a un ideal de belleza antiguo. No hay que responder simplemente a cómo las formas griegas llegaron al siglo XV sino también a por qué la astrología de tipo indio vuelve a hallar en Italia un valor de uso, a por qué el saber medieval sobrevive en Leonardo Da Vinci y a por qué ciertos rasgos del gótico septentrional están presentes en el Renacimiento más clásico29. La supervivencia, dice Didi-Huberman, impone la paradoja de que las cosas más antiguas vienen a veces después de las cosas menos antiguas y desestabiliza así toda periodización histórica. Es por tanto (i) un concepto estructural que cabe aplicar de manera transversal sobre cualquier división cronológica. Esto es: para cada periodo histórico es posible y necesario rastrear en él las supervivencias de cualquier otro periodo cronológicamente anterior. Implica que en todo momento de la historia hay siempre (a priori) un pasado operando de manera no explícita. En este sentido "la supervivencia hace más compleja la historia: libera una especie de 'margen de indeterminación' en la correlación histórica de los fenómenos. El después llega casi a liberarse del antes cuando se une a ese fantasmático 'antes del antes' superviviente." 30 Así las cosas, las ideas de tra-

\footnotetext{
28 Didi-Huberman 2009, op.cit. (nota 5), pp. 59-60.

29 Didi-Huberman 2009, op.cit. (nota 5), p. 76.

30 Ibidem. p. 76.
} 
dición y transmisión se vuelven terriblemente complejas. La noción de supervivencia implica (ii) un modelo de tiempo propio de las imágenes que anacroniza las relaciones entre los fenómenos históricos. Ambas, tradición y transmisión, pueden tomar la forma de procesos no lineales - olvidos y redescubrimientos, inhibición y destrucción, de asimilaciones e inversiones de sentido - que terminan por anacronizar la historia. La supervivencia anacroniza a la vez, pues, el presente, el pasado $\mathrm{y}$ hasta el futuro.

El presente (ii.1) se vuelve irreductible a algo así como el espíritu de una época; los individuos - los artistas y otros hombres de cultura, por ejemplo - que viven en un mismo momento histórico no tienen por qué comprenderse ni por qué compartir estilo. De hecho es bastante frecuente que no se entiendan entre sí. El espíritu del tiempo como decía Goethe y Warburg gustaba repetir no es en realidad sino el espíritu del honorable historiador en el que ese tiempo es pensado. Si uno se toma suficientemente en serio la exigencia de pensar los fenómenos históricos como depositarios de supervivencias de origen diverso, entonces (ii.2) el pasado mismo también se anacroniza. Si la exigencia se hace recursiva, si a las propias supervivencias se las señala como impuras, lo que cabría situar en origen, al que desde ahora le faltará también la originalidad, habrá que concebirlo asimismo transitado por sus propias supervivencias. Si el Renacimiento fue analizado por Warburg como un tiempo impuro, era también porque el pasado cuyas fuerzas vivas convocaba - la Antigüedad clásica - tampoco tenía nada de origen absoluto. El origen forma, en consecuencia, una temporalidad impura de hibridaciones y sedimentos, de pretensiones y perversiones." 31 Baste para ilustrar qué significa la anacronización del pasado recordar que las formas griegas que el Renacimiento recuperó ya estaban en la Antigüedad trabajadas por supervivencias de modelos orientales que habían sufrido un largo proceso de alteración. Por último, (ii.3) la supervivencia en cuanto concepto estructural y fuerza constitutiva del surgimiento de estilos tiende a modificar lo que en cada momento nos está dado esperar: el porvenir se vuelve incierto porque podría estar habitado por elementos de un pasado que nosotros creemos definitivamente perdido.

La anacronización de las dimensiones temporales es completa. Las supervivencias, no hemos dejado de decirlo, están ahí, en las imágenes mismas, son parte de ese tiempo complejo en el que consiste ser una imagen plástica. Pero también hemos repetido hasta el cansancio que pasan desapercibidas a la mirada habitual del historiar y por tanto parece necesario decir algo a propósito (iii) de la manera en la que están ahí en la imagen. "Podré decir que hay un resto de vida sólo cuando pueda decir que eso puede todavía moverse, sea del modo que sea." 32 A la pregunta acerca de cómo están las supervivencias en la imagen - ¿cuáles son las formas corpo-

31 Ibídem. p. 78.

32 Didi-Huberman 2009, op.cit. (nota 5), p. 172. 
rales del tiempo superviviente? - debería responder el concepto, absolutamente central en Warburg, de Pathosformel, fórmula del pathos. Este designa la existencia material de la supervivencia y hace referencia a una constelación de elementos proporcionados por la tradición que de manera variable se configurarían en la ejecución de cada imagen particular y en base a los cuales podrían observarse analogías entre ellas. Las diversas fórmulas patéticas se corresponderían con las representaciones de las formas afectivas primitivas, tales como los gestos de dolor - que cabe encontrar, por ejemplo, en el Laocoonte o en la muerte de Orfeo. 33 Pero como no basta, según se nos dice, con hallar algunas analogías entre diferentes representaciones de un mismo tipo de gestualidad para hacer emerger su vinculación genealógica, el concepto de supervivencia exige también (iv) algo parecido a un método para poner en evidencia las fórmulas del pathos en las que se realiza. Esta método Didi-Huberman tiende a identificarlo, ya lo señalamos, con el del psicoanalista, pero tampoco ignora que si Warburg lo puso en práctica en algún lugar fue en el Atlas Mnemosyne donde no hay ninguna referencia a la ciencia freudiana. ${ }^{34}$ ¿Por qué las supervivencias exigen ese Atlas? ¿Cómo funciona el extraño proyecto de Warburg? Se trataría de un dispositivo que a fuerza de disponer unas imágenes junto a otras bajo un mismo título - esta sería su descripción más sencilla - lograría "desplegar visualmente las discontinuidades del tiempo presentes en toda secuencia de

33 Las indicaciones de Didi-Huberman son a este respecto más desordenadas que nunca. Me permito a falta de una mayor elaboración, citar un largo pasaje de Giorgio Agamben que proporciona algo de luz - bien es cierto que no demasiada - sobre qué significa el concepto de Pathosformel: "Quizá el mejor modo de comprender su sentido sea el ponerlo en relación con el uso del término 'fórmula' en los estudios de Milman Parry sobre el estilo formular en Homero [...] [Mostró]que la técnica de composición oral de la Odisea se fundaba sobre un vasto, aunque limitado repertorio de combinaciones verbales (los célebres epítetos homéricos: podas okys, pie veloz, korythaiolos, yelmo deslumbrante, polytropos, de muchas tretas, etcétera), configuradas rítmicamente de un modo que permitía su adaptación a secciones del verso y compuestas a su vez de elementos métricos intercambiables, modificando los cuales el poeta podía variar la propia sintaxis sin alterar la estructura métrica. Albert Lord y Gregory Nagy han demostrado que las fórmulas no rebosan de material semántico sólo para poder rellenar un segmento métrico, sino que, por el contrario, el metro deriva probablemente de la fórmula transmitida por la tradición. De la misma manera, la composición formular implica que no es posible distinguir entre creación y performance, entre original y repetición. En palabras de Lord 'el poema no se compone para la ejecución, sino en la ejecución'. Pero esto significa que las fórmulas, exactamente como la Pathosformel de Warburg, son híbridos de materia y de forma, de creación y performance, de primeridad y repetición. Tómese la Pathosformel Ninfa, a la que está dedicada la pancha 46 del Atlas Mnemosyne. La plancha contiene veintiséis fotografías, desde un relieve longobardo del siglo VII hasta el fresco de Ghirlandaio en Santa Maria Novella (...), desde la portadora de agua de Rafael hasta la campesina toscana fotografiada por Warburg en Settignano. ¿Dónde está la ninfa? ¿En cuáles de sus veintiséis epifanías reside? Se malentiende la lectura del Atlas si se busca entre ellas algo así como un arquetipo o un original del que las otras derivarían. Ninguna de las imágenes es e-l origina, ninguna es simplemente una copia.” Agamben, G, Ninfas, Valencia, Pre-textos, 2010, pp. 18-19.

34 Claro que Didi-Huberman lee el Atlas con la ayuda de Binswanger y atribuye a Warburg y a su atlas un funcionamiento que se asemeja al método maniaco descrito por el psiquiatra. 
la historia", "ofrecer los jalones visuales de una memoria impensada de la historia, lo que Warburg nunca habría dejado de llamar Nachleben." 35 Mediante este montaje de imágenes heterogéneas Warburg habría conseguido hacer hablar a los muertos, mostrar las supervivencias que asedian al Renacimiento, poner de manifiesto la manera en que las fórmulas del pathos se asocian y ello como en un fogonazo, sin recurrir a ningún esquema explicativo o narración histórica. El dispositivo Mnemosyne, la disposición de las láminas que lo componen, proporcionaría de este modo un cierto conocimiento sobre cada una de las imágenes que en él aparecen y sobre el Renacimiento en general.

Cualquier que se haya enfrentado a las láminas que componen Mnemosyne no habrá podido dejar de sentirse realmente perturbado. Igual que tras leer ese otro atlas que es el Libro de los Pasajes de Walter Benjamin, uno sale con la extraña sensación de saber algo esencial sobre el periodo histórico del que tratan - el Renacimiento o el Paris del siglo XIX - pero no sabe muy bien qué es eso que sabe. 36 "Resulta imposible - escribe Didi-Huberman - saber claramente en qué dirección quiso Warburg orientar nuestra mirada o de qué significación exacta es portadora, según él, la relación entre las imágenes próximas entre sí. Cuanto más se mira, más densas e intrincadas parecen las relaciones." 37 Pensamos que ante una situación así solo caben dos opciones. La primera es asumir, como Didi-Huberman hace, que este es un método poco prudente pero, quizá por eso mismo, el mejor del que puede disponer la Historia y la Historia del Arte. A partir de entonces habría que ponerlo en práctica y realizar la loca exigencia de pensar - ¿pero qué significa pensar aquí donde parece no haber lenguaje? - una imagen en relación con todas las demás.

La otra opción consiste en admitir que todas estas nociones solo están esbozadas o que les falta su articulación - pese a que se presenten como conceptos acabados. En este caso seguiría siendo posible que un concepto de imagen y un modelo de tiempo construidos siguiendo esas indicaciones, que son esencialmente correctas, sirvieran para enriquecer el discurso de la Historia del Arte y hacer justicia a la complejidad de sus objetos. Si esta empresa llegara a un puerto, entonces se podría intentar extender la ontología regional de la imagen artística así ganada hasta la formulación de una lógica general de tipo espectral.

\footnotetext{
35 Didi-Huberman 2009, op.cit. (nota 5), p. 430.

36 Mi primer contacto directo con el trabajo de Didi-Huberman tuvo lugar el 26 de diciembre de 2010 cuando él mismo inauguró la exposición «Atlas ¿Cómo llevar el mundo a cuestas?» en el Museo Reina Sofía de Madrid. Aunque no pude escuchar aquella conferencia - aforo completo - guardo un grato recuerdo de la exposición. Es más, creo que aquella tarde comprendí algo que era importante pero sería incapaz de hablar sobre ello. Al salir, como Chesterton escribió en cierta ocasión, la cabeza me pesaba como si hubiera bebido champán, cosa que no pude explicarme nunca.
}

37 Didi-Huberman 2009, op.cit. (nota 5), p. 420. 